\title{
Suppressing Aluminum Carbide in Welding Aluminum Silicon Carbide Composite
}

\author{
Mitul A. Kothari and Wayne N.P. Hung

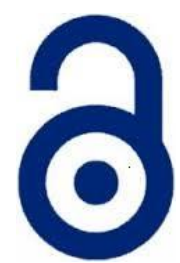 \\ Received: 12 March 2018 \\ Accepted: 17 March 2018 \\ Published: 30 March 2018 \\ Publisher: Deer Hill Publications \\ (c) 2018 The Author(s) \\ Creative Commons: CC BY 4.0
}

\begin{abstract}
Weldability of aluminum-based metal matrix composite A359/SiC/10p using gas tungsten arc welding and R356.0 filler material is investigated. The welding current, welding speed, and preheat temperature affect the weld quality significantly. Finite element analysis is successfully applied to map the weldment temperature during preheating and welding. During mechanical testing of welded specimens, a crack propagates in the parent composite or in the weld, but not in the stronger zone between the weld and the parent material. The weld region contains reasonably uniform distribution of $\mathrm{SiC}$ particles due to high viscosity of the molten weld and its fast cooling rate. Proper control of heat input and addition of silicon-rich filler material hinder the interfacial reaction between aluminum matrix and the reinforcing SiC particles, and successfully suppress the formation of harmful aluminum carbide flakes in the weld. The average tensile and flexural strengths of optimally welded specimens approach those of the parent composite while their ductility exceeds that of the parent material.
\end{abstract}

Keywords: Gas tungsten arc welding, metal matrix composite, silicon carbide, cast aluminum, aluminum carbide, free energy of formation.

\section{INTRODUCTION}

Advanced metal matrix composites (MMCs) combine the advantages of tough metal matrix and hard reinforcement to enhance their mechanical and/or physical properties. Commercially available MMCs with excellent specific strength, high thermal conductivity, controllable thermal property, and good wear resistance have found their ways into many practical applications in bio-medical, electronics, aerospace, marine, machinery, sporting goods, metrology, and transportation. Although fiber reinforced composites have been successfully produced, the particle reinforced MMCs are more popular since they behave isotropically and can be produced economically. Raw MMCs can be manufactured by casting, bulk forming, or powder metallurgy techniques, but a full application of MMCs still depends on suitable processes that can repeatedly and economically shape a selected composite into useful components. Studies of MMC's machinability show that traditional machining processes can be successfully performed with diamond cutting tools and MMCs can also be shaped by other nontraditional techniques. Weldability of MMCs to themselves or to other engineering materials has been investigated by many researchers but there are remaining technical issues to be solved. In addition to common welding defects, the thermal-induced metallurgical defects such as agglomeration of the reinforcing particles and formation of aluminum carbide $\mathrm{Al}_{4} \mathrm{C}_{3}$ in $\mathrm{Al}$-SiC composites have been reported [1-3]. Although low temperature joining processes such as adhesive bonding, brazing, or diffusion bonding can be utilized, the resulting low joining strength and high cost of diffusion bonding are still the concern for high volume production. Joining of MMC components among varieties of shapes and sizes using a suitable fusion technique is still a promising alternative if the harmful aluminum carbide $\mathrm{Al}_{4} \mathrm{C}_{3}$ byproduct can be avoided.

The objectives of this research are to (i) utilize gas tungsten arc welding (GTAW) and a suitable filler material to study the weldability of A359 cast aluminum reinforced with SiC particulates, and (ii) identify suitable process parameters to achieve high quality weld while suppressing the formation of aluminum carbide.

\section{LITERATURE REVIEW}

The Aluminum Association of America recommends nomenclature for metal matrix composite as "Matrix/Reinforcement/Volume fraction and reinforcement type." The reinforcement type can be either particle (p),

M.A. Kothari and W.N.P. Hung 四

Texas A\&M University

E-mail: Hung@tamu.edu

Reference: M.A. Kothari and W.N.P. Hung (2018). Suppressing Aluminum Carbide in Welding Aluminum Silicon Carbide Composite. International Journal of Engineering Materials and Manufacture, 3(1), 41-54. 
whisker ( $w$ ) or fiber ( $f$ ). For example, the nomenclature $\mathrm{A} 359 / \mathrm{SiC} / 10 \mathrm{p}$ in this study indicates the MMC containing A359 aluminum matrix and 10 volume $\%$ of $\mathrm{SiC}$ particles as reinforcement.

Welding of MMCs may produce solidification defects, metallurgical defects, or process related defects. Since most reinforcing ceramics have different physical and mechanical properties from the metallic matrix, such differences can lead to pronounced particle segregation effects when the matrix is in the molten state. Below a certain solidification temperature, reinforcements can be pushed ahead of the solidification front, forming a non-uniform distribution of the reinforcement in the weld region thus weakening this area. When welding 6061- $66 / \mathrm{Al}_{2} \mathrm{O}_{3}$, Schwartz [2] found that adding a filler metal at unfavorable conditions could alter the matrix and cause a non-uniform distribution of the reinforcement particles in the weld region. The fluidity of the weld pool affects by the SiC reinforced particles and how they are distributed. In the molten state the composite metal weld pool has higher viscosity than that of the matrix alone; therefore, it does not flow well. High viscosity also leads to a lower heat transfer by convection mechanism in the weld pool, which affects the resulting microstructures and stress distributions in the MMCs. This leads to an increasing numbers of porosity and weld-lines in the weld metal, as low fluidity may not be sufficient to ensure the filling of the entire weld pool region. Solidification problems may result in unfavorable distribution of the reinforcements and non-uniform packing density of the reinforcement across the weld region [3].

\subsection{Fusion welding of Al-SiC composites}

One major difficulty with most of the fusion welding processes for MMCs is that a prolonged contact between a molten metal matrix and reinforcement can lead to undesirable chemical reactions. Under suitable conditions, liquid aluminum would react with $\mathrm{SiC}$ reinforcement to precipitate the brittle and harmful aluminum carbide $\mathrm{Al}_{4} \mathrm{C}_{3}$ while increasing the silicon content upon cooling of molten metal matrix.

$$
3 \mathrm{SiC}+4 \mathrm{Al} \leftrightarrow \mathrm{Al}_{4} \mathrm{C}_{3}+3 \mathrm{Si}
$$

These needle-like $\mathrm{Al}_{4} \mathrm{C}_{3}$ particles embrittle the weld and should be avoided. Studies of the interfacial matrix/reinforcement reactions and fracture mechanisms of welded $\mathrm{Al} / \mathrm{SiC}$ have revealed that the interfacial failure increases in welded metal due to the formation of $\mathrm{Al}_{4} \mathrm{C}_{3}$. In addition, the resulting silicon product released from the decomposition of $\mathrm{SiC}$, stated in reaction (1), would also degrade the weld. Such embrittlement is worsened in the presence of other intermetallic compounds of $\mathrm{Si}, \mathrm{Al}$, and Fe. Under these circumstances, Urena et al. [4,5] reported that tensile strength of welded specimens was less than $50 \%$ of that from the base material.

Previous work on welding of $6061 / \mathrm{SiC} / 10 \mathrm{p}$ by Chen et al. [6], revealed that GTAW tended to produce more $\mathrm{Al}_{4} \mathrm{C}_{3}$ platelets than pulsed-GTAW. Gopinathan et al. [7] studied $\mathrm{CO}_{2}$ laser welding of $A 356 / \mathrm{SiC}$ containing different amounts of volume fractions of $\mathrm{SiC}$ particles. The authors calculated the thermal fields in the weld region and yielded the critical temperature and conditions for $\mathrm{Al}_{4} \mathrm{C}_{3}$ formation. The critical temperature required for $\mathrm{Al}_{4} \mathrm{C}_{3}$ formation was calculated and verified experimentally to be $827^{\circ} \mathrm{C}$ when the critical cooling rate was about $12,000{ }^{\circ} \mathrm{K} / \mathrm{sec}$. A cooling rate above this critical cooling rate tended to decrease the extent of the interface reaction. Ellis [3] studied the thermodynamics in fusion welding of $\mathrm{Al} / \mathrm{SiC}$ and predicted the critical temperature of $727^{\circ} \mathrm{C}$ for the formation of $\mathrm{Al}_{4} \mathrm{C}_{3}$ plates. In the presence of moisture, the $\mathrm{Al}_{4} \mathrm{C}_{3}$ may decompose, release methane gas, and increase the joint susceptibility to corrosion cracking while degrading the joint strength. Pitting corrosion was observed in the heat affected zone (HAZ) of welded Al-based MMCs, concluded by Mathers [8]. Another study by Park and Lucas [9] suggested that $\mathrm{Al}_{4} \mathrm{C}_{3}$ can be formed around $650^{\circ} \mathrm{C}$ after prolonged contact between $\mathrm{SiC}$ and molten aluminum, and the $\mathrm{Al}_{4} \mathrm{C}_{3}$ can be disintegrated in less than 120 hours when exposed to a wet aqua-environment. Other studies by Dahotre et al. $[10,11]$ on laser joining of $\mathrm{A} 356 / \mathrm{SiC}$ composites containing various volume fractions of $\mathrm{SiC}$ particles showed that an increasing of energy densities would promote the $\mathrm{SiC}$ particle dissolution and the formation of $\mathrm{Al}_{4} \mathrm{C}_{3}$ particles. The duty cycle also had direct impact on how the weld microstructure would change. Similarly, Hung et al. [12] found that YAC laser machining also formed the $\mathrm{Al}_{4} \mathrm{C}_{3}$ precipitates in $\mathrm{A} 359 / \mathrm{SiC} / 20 \mathrm{p}$, and other defects such as thermal cracks, redistribution of $\mathrm{SiC}$, and voids. The latter was typical in cast and welded MMCs due to low fluidity of the molten matrix and non-uniform shrinkage upon solidification.

Fusion welding was also applied to weld MMCs with other monolithic materials. Since welding of aluminumbased $\mathrm{MMC}$ with $\mathrm{SiC}$ reinforcement would form the harmful $\mathrm{Al}_{4} \mathrm{C}_{3}$, some researchers apply alloying techniques to suppress the formation of $\mathrm{Al}_{4} \mathrm{C}_{3}$. Gomez et al. [13] used metal inert gas welding and selected $\mathrm{Al}-\mathrm{Si}$ and $\mathrm{Al}-\mathrm{Mg}$ as filler materials to join the $7005 / \mathrm{Al}_{2} \mathrm{O}_{3} / 10 p$ composite with 7020 aluminum. The joint strength reached $60 \%$ of that from the parent material and can be further improved to $95 \%$ by a post-weld heat treatment process. In laser welding study, Wang et al. [14] sandwiched a $0.3 \mathrm{~mm}$ titanium foil between $6061 / \mathrm{SiC} / 25 \mathrm{p}$ specimens and exposed it to $\mathrm{CO}_{2}$ laser with $3.2 \mathrm{kw} / \mathrm{mm}^{2}$ power density. The energetically favorable titanium carbide $\mathrm{TiC}$ and other compounds ( $\mathrm{Ti}_{5} \mathrm{Si}_{3}$, $\mathrm{Al}_{3} \mathrm{Ti}$, or $\mathrm{Ti}_{2} \mathrm{AlC}$ ) were formed in the weld instead of $\mathrm{Al}_{4} \mathrm{C}_{3}$. However, some aluminum carbide $\mathrm{Al}_{4} \mathrm{C}_{3}$ and similar precipitates $\left(\mathrm{Al}_{4} \mathrm{SiC}_{4}\right.$, and $\left.\mathrm{Al}_{4} \mathrm{Si}_{2} \mathrm{C}_{5}\right)$ were still formed in the heat affected zone away from the titanium rich weld zone.

\subsection{Solid State Welding of Al-Si Composites}

Several solid state welding techniques have been explored to join MMCs. Some researchers use friction stir welding technique to join MMC components or MMCs with other engineering alloys. A stirrer rotates, plunges into the joint junction to (i) plasticize the materials, (ii) forge the different materials together, and then (iii) form a joint at a temperature that is below melting temperature of the weldment. Kannan et al. [15] friction welded 6061- 
$\mathrm{T} 6 / \mathrm{Al}_{2} \mathrm{O}_{3} / 10 \mathrm{p}$ onto 304 stainless steel. The stainless steel plate was covered with an electroplated silver layer of 16 $\mu \mathrm{m}$ thick. Having the silver interlayer reduced $\sim 3 \%$ number of fractured reinforcing particles in the weld. Lee et al. [16] friction welded 6092/SiC/17.5p composites and considered the effects of axial force, rotation speed, tool feed rate, lead angle, and plunge depth as process variables. Excessive abrasive wear of the stirrer was recognized, and a suitable coated stirrer was sought; an inexpensive boron carbide coating was tried unsuccessfully despite of its inherent low coefficient of friction. The optimally welded composite had tensile strength of $300 \mathrm{MPa}(43.5 \mathrm{ksi})$ which was $65 \%$ of the parent material strength. After a post-weld solution heat treating and aging to the T6 condition, the joint strength reached up to $426 \mathrm{MPa}(61.9 \mathrm{ksi})$ which is $93 \%$ of the parent material's strength. Friction welding, however, produced a soft weld with hardness of $40 R_{B}$ compared to $80 R_{B}$ of the parent material. Recognizing wear of a stirrer was one of the major drawbacks of friction stir welding for MMCs, Prater [17] proposed to monitor stirrer wear using the current from the stirrer motor and found that the stirrer wear was proportional to stirrer rotational speed and welding distance, but it was inversely proportional to the stirrer feed rate. Zhou et al. [18] also studied friction stir welding of $6061 / \mathrm{Al}_{2} \mathrm{O}_{3} / 10 \mathrm{p}$ and 304 stainless steel by varying the rotational speed, pressure, and welding time. They reported lots of broken particles at the joint, reduced particle spacing in the weld, and delaminated matrix/reinforcement interfaces that led to final weld fracture in a notched tensile specimen. When comparing against relevant tensile strengths (517 MPa for 304 stainless steel, $310 \mathrm{MPa}$ for 6061 and $338 \mathrm{MPa}$ for the parent MMC), the tested joint strength were in the range $225-337 \mathrm{MPa}$ with is $66-99 \%$ of the strength for the parent MMC. Bozkurt [19] friction stir welded $2174 / \mathrm{SiC} / 25 \mathrm{p}$ and concluded that the rotational speed of a stirrer had higher influence to the weld quality than the stirrer feed rate. The resulting weld strengths were $263-366 \mathrm{MPa}(58-80 \%)$ as compared to $454 \mathrm{MPa}$ of the parent composite. Jayaraman et al. [20] experimentally found that the maximum joint strength of friction stir welded cast LM6 A413 was $165 \mathrm{MPa}$, which was $57 \%$ of the tensile strength tensile (290 MPa) of the parent cast aluminum. Spot friction welding to form local MMC joints was successfully performed by Miller et al. [21]. These researchers added steel particles between 6111-T6 aluminum and then spot friction welded the sandwiches to achieve an increment of $25 \%$ higher for shear strength.

Although friction stir welding of aluminum MMCs with SiC reinforcement can avoid formation of aluminum carbide due to its inherent low processing temperature, this process is constrained by specific geometries, limited to certain joint types, and damages to the reinforcement by breaking the particles and their surface coatings.

\subsection{Other Joining Techniques for Al-Si Composites}

Other researchers explored different joining techniques for aluminum-based MMCs. Huang et al. [22] diffusion bonded 6063/SiC/15p with Al-Si and Al-Cu powders between MMC specimens. The authors reported that the preferred Al-Si powders provided a better joint after heating the weldment to $580-605^{\circ} \mathrm{C}$ at $300 \mathrm{kPa}$ in vacuum for 15-120 minutes. However, shear strength of the best joint reached only $42 \%$ (50 MPa) of the $120 \mathrm{MPa}$ shear strength (241 MPa tensile strength) of the 6063-T6 matrix material. Rosenberg et al. [23] patented another technique to weld MMC by using high power X-ray at the minimum power density of $10^{4} \mathrm{w} / \mathrm{cm}^{2}$. This technique was more favorable than electron beam welding since the latter, with a couple of magnitudes higher in power density, would cause more welding defects due to superheating and evaporating of materials in the weld.

Among all joining techniques, fusion welding of Al-Si composites is still the most economical process if the silicon carbides can be avoided. The following sections describe the experiments and results from microstructural investigation and mechanical testing.

\section{EXPERIMENTS}

Butt joints of A359/SiC/10p were welded with a Lincoln Electric Square Wave TIC 175 Pro in this study. An $\varnothing 2.54$ mm electrode containing $99.5 \%$ tungsten was ground to $90^{\circ}$ tip cone angle for each weld. A series of factorial experiments were performed at high and low values to identify significant variables or their combinations. The variables include welding speed $(120-250 \mathrm{~mm} / \mathrm{min})$, and AC welding current (90-110 A). Argon shielding gas was utilized at a constant flow rate of $215 \mathrm{~cm}^{3} / \mathrm{sec}$. The R356.0 filler rods with $\varnothing 4.76 \mathrm{~mm}(\varnothing 3 / 16$ inch) diameter were used for all experiments. Optimal conditions were predicted from the Design Expert software version 6.0 based on these dominant variables.

Table 1 lists and compares the chemical compositions of the A359 aluminum matrix and the filler material R356.0. This filler material was chosen to closely match with the matrix material, although slightly lower silicon content was noticed. The aspect ratio of the reinforcing SiC particles is 1.5:1 with the mean particle size of $12.8 \pm 1.0 \mu \mathrm{m}$; $94 \%$ of population size $>5 \mu \mathrm{m}$ and $3 \%$ of population $>25 \mu \mathrm{m}$. Specimens of permanent-mold cast A359/SiC/10p MMCs were obtained commercially and were milled to remove all outer layers and possible defects. Pre-welding grooves of $90^{\circ}$ angle and $2.5 \mathrm{~mm}$ depth were milled on all samples and later welded together with a filler material. Other physical properties of the A359/SiC/10p include $2710 \mathrm{~kg} / \mathrm{m}^{3}$ density, $0.450 \mathrm{cal} / \mathrm{cm} / \mathrm{s} /{ }^{\circ} \mathrm{K}$ thermal conductivity, 0.235 $\mathrm{cal} / \mathrm{g} /{ }^{\circ} \mathrm{K}$ specific heat, and $24.8 \times 10^{-6} /{ }^{\circ} \mathrm{K}$ average coefficient of thermal expansion. Table 2 lists mechanical properties of selected permanent-mold cast MMCs.

The ABAQUS finite element software was used to calculate and map temperatures around and in the weld pool. The simulated temperatures were validated by comparing against actual readings from the thermocouples, located around a weld pool, during an actual pre-heating process. For simplicity, the bulk properties of A359 aluminum matrix were used in the calculation while ignoring the small $10 \%$ volume fraction of SiC in the MMC. A tetrahedral 
type of element was selected to mesh the FEA model to suit the triangular geometry of the weld joint design. The mesh size was user-defined, wherein the mesh size was made finer along the welding surface and near the thermocouple positions for better accuracy.

A GTAW torch was rigidly attached to the motorized Victor Mod 100 rail. A steel ruler and stop watch were used to calibrate the rail speed (welding speed) in both forward and backward directions. To evaluate the weld quality, Vicker microhardness was measured with a Buehler Micromet 2 digital microhardness tester by loading a Vicker diamond indenter at $25 \mathrm{gf}$ load for 10 seconds and aiming in the matrix while avoiding colliding of the small indenter tip on a $\mathrm{SiC}$ reinforcement.

The United SFM 30 universal tester was utilized for bending and tensile tests. A four point bending specimen (30 $\times 15 \times 125 \mathrm{~mm}$ ) was bent to crack open a weld in tensile mode following the ASME Sec IX QW-462.3 testing standard. A tensile specimen $(5 \times 15 \times 125 \mathrm{~mm})$ was designed to minimize machining-induced defects after welding. Three slots were sawed on a pre-welded sample: the central slot would force a crack to propagate through the butt weld, and the other two slots were to streamline the line of force in the specimen gauge length (Fig. 1a).

Preheating in the neighborhood of a weld was required for temperature control. The entire weldment was first preheated to $150^{\circ} \mathrm{C}$ on a hot plate before welding, transferred onto a welding fixture, and preheated again with the GTAW torch along lines on left and right of a welding groove. A grooved MMC specimen with three embedded thermocouples was fabricated. Three type- $\mathrm{K}$ thermocouples were attached to drilled holes below the preheat area, and near the V-notch (Figs. 1b and 2). The temperature data logger, Datapaq Reflowpaq 2000 model RP0061, was used for acquiring temperature data from the thermocouples. The GTAW torch preheating was performed at $90 \mathrm{~A}$ of AC current and $4 \mathrm{~mm}$ torch length. The preheating sequence and welding steps were summarized in Table 3.

Metallographic samples were prepared by first sectioning the weld beads perpendicularly to the welding direction, epoxy mounting with the Buehler Simplimet 2 press, following by hand grinding, polishing, and then etching for microstructural study. Hand grinding with 240, 320, 400, and 600 grit abrasive papers were performed sequentially in flowing water. The samples were rinsed with clean water after each step to remove possible abrasive particles and chips, blown dried with dry compressed air before proceeding to the next step.

Table 1: Compositions of R356.0 filler material [24] and A359 aluminum matrix [25].

\begin{tabular}{llllllllll} 
& $\mathrm{Si}$ & $\mathrm{Fe}$ & $\mathrm{Cu}$ & $\mathrm{Mg}$ & $\mathrm{Zn}$ & $\mathrm{Ti}$ & $\mathrm{Mn}$ & Others & $\mathrm{Al}$ \\
\hline A359 & 8.50 & 0.20 & 0.20 & $0.25-0.45$ & 0.10 & 0.20 & 0.10 & 0.15 & Remain \\
R356.0 & $6.5-7.5$ & 0.20 & 0.20 & $0.25-0.45$ & 0.10 & 0.20 & 0.10 & 0.15 & Remain \\
\hline
\end{tabular}

Table 2: Mechanical properties of permanent-mold cast Al-SiC MMCs [25].

\begin{tabular}{llllll}
\hline Material & $\begin{array}{l}\text { Tensile strength } \\
(\mathrm{MPa})\end{array}$ & $\begin{array}{l}\text { Yield strength } \\
(\mathrm{MPa})\end{array}$ & $\begin{array}{l}\text { Elongation } \\
(\%)\end{array}$ & $\begin{array}{l}\text { Elastic modulus } \\
(\mathrm{GPa})\end{array}$ & $\begin{array}{l}\text { Rockwell } \\
\text { hardness, } \mathrm{H}_{\mathrm{B}}\end{array}$ \\
\hline A356-T6 & $255-276$ & 200 & 6.0 & 75.2 & 55 \\
A359/SiC/10p-T6 & $310-338$ & $283-303$ & 1.2 & 86.2 & 73 \\
A359/SiC/20p-T71 & 262 & 214 & 1.9 & 98.6 & - \\
A359/SiC/20p-O & 221 & 165 & 2.8 & 98.6 & - \\
\hline
\end{tabular}

Table 3: Preheating and welding sequences

\begin{tabular}{clll}
\hline Step & \multicolumn{1}{c}{ Process } & Duration (sec) & Cumulative time (sec) \\
\hline 1 & Preheat to $150^{\circ} \mathrm{C}$ on a hot plate & 1800 & 1800 \\
2 & $\begin{array}{l}\text { Preheat with GTAW torch above the left thermocouple, } 5 \\
\text { passes @19 sec/pass }\end{array}$ & 95 & $1800+95$ \\
3 & Idle & 15 & $1800+110$ \\
4 & $\begin{array}{l}\text { Preheat with GTAW torch above the right thermocouple, } 2 \\
\text { passes @17.5 sec/pass }\end{array}$ & 35 & $1800+145$ \\
5 & Idle & 20 & $1800+165$ \\
6 & Weld with GTAW torch along the $90^{\circ}$ groove & 30 & $1800+195$ \\
7 & Cool in air & 300 & $1800+495$ \\
\hline
\end{tabular}




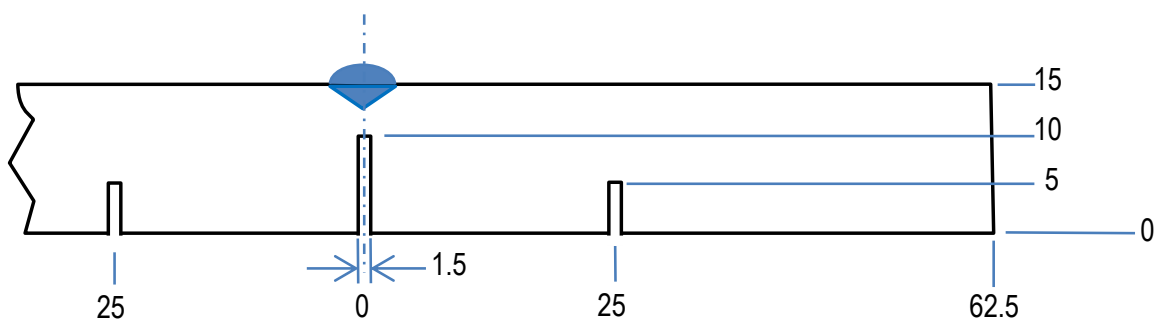

Figure 1a: Modified tensile specimen with three sawed slots. All dimensions are in millimeters.

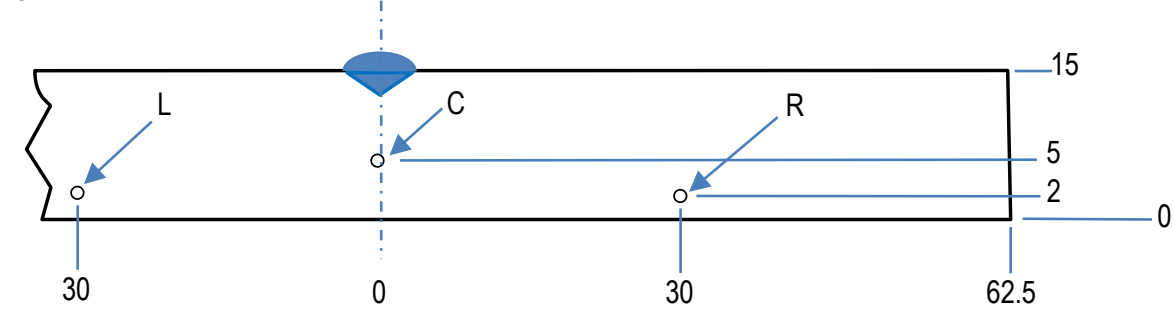

Figure 1b: Setup for temperature test. Three thermocouples are located at left ( $L)$, right $(R)$ and below the center (C) of a weld. All dimensions are in millimeters.

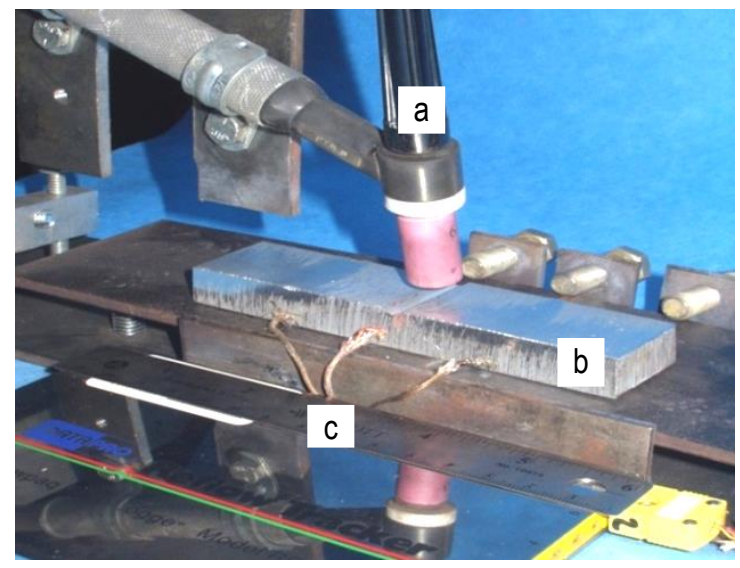

Figure 2: Welding temperature measurement with (a) GTAW gun, (b) butt joined MMC samples, and (c) three thermocouples at left, right, and below a weld groove.

After the final grinding, the samples were polished on a Buehler Vibromet 2 vibrating polisher using diamond pastes of $15 \mu \mathrm{m}, 9 \mu \mathrm{m}, 6 \mu \mathrm{m}$, and $1 \mu \mathrm{m}$ sequentially. Next, they were cleaned with isopropyl alcohol between grinding/polishing steps in an ultrasonic cleaner to remove any remaining particles from previous steps. A specimen was etched in Keller's reagent composed of $2 \mathrm{ml} \mathrm{HF}(48 \%), 3 \mathrm{ml} \mathrm{HCl}, 5 \mathrm{ml} \mathrm{HNO}$, and $190 \mathrm{ml} \mathrm{H}_{2} \mathrm{O}$. The resulting microstructure was observed and measured on a measuring microscope Olympus SMT6 with $0.1 \mu$ m resolution. To identify silicon carbide in A359/SiC MMC for comparison purpose, an MMC specimen was laser drilled (YAC, $1 \mu \mathrm{m}$ wavelength, $200 \mathrm{~W}$ power) to intentionally produce silicon carbide in the specimen. Microstructure of the laser drilled specimen was prepared with similar procedures as for the welded specimen for comparison.

\section{RESULTS AND DISCUSSIONS}

Since the GTAW torch was attached to the motorized Victor Mod rail, a chart is obtained to calibrate and quantify the welding speed. The actual rail speed is linearly proportional to the speed calibration dial on the rail. The measured speed is consistent and repeated when moving the rail forward or backward (Fig. 3). 


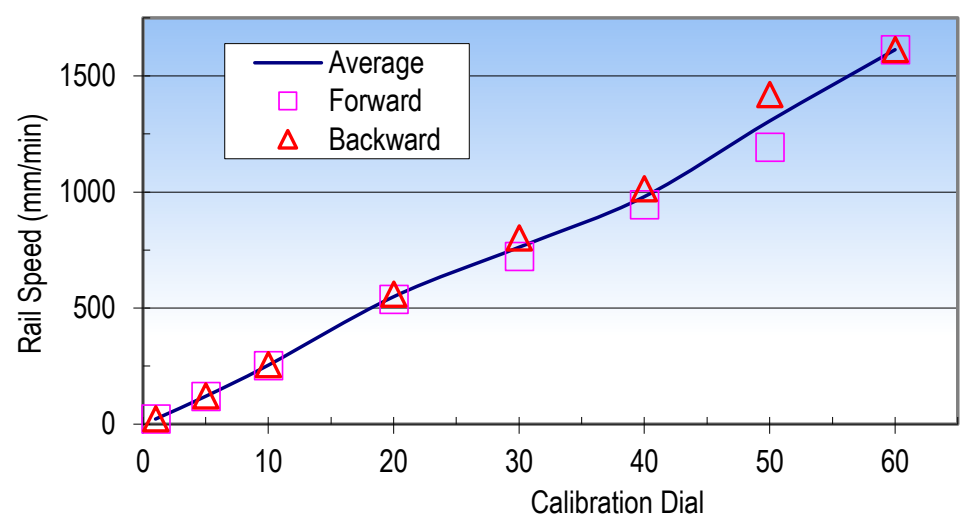

Figure 3: Calibration of rail speed (welding speed) for the Victor Mod 100 rail.

\subsection{Weld temperature estimation}

Finite element simulation was used to estimate temperature at the weld and heat affected zones during welding. Actual temperature during preheating was measured and compared with calculated data to verify the validity of the simulation. Figures $4 \mathrm{a}, 4 \mathrm{~b}$, and $4 \mathrm{c}$ show how temperatures and their gradients change with time during the preheating sequences. Although a specimen was initially heated to $150^{\circ} \mathrm{C}$ on a hot plate, its surface temperature dropped to nearly $100^{\circ} \mathrm{C}$ after transferring and fixturing a weldment onto a welding table at room temperature. Additional preheating with a GTAW torch was necessary to maintain temperature before welding. When the surface above the left thermocouple was heated five times along a line $30 \mathrm{~mm}$ from the weld, the average temperatures of all three thermocouples rose linearly during the preheating time $(0-95 \mathrm{sec})$. The temperature gradients then reduced when the heating torch was off while moving to the right location (95-110 sec), after which the temperatures rose again when preheating twice at the right location (110-145 sec). Reasonable agreement was obtained between the measured temperatures and the resulting finite element data at three thermocouple locations (left, right, and below a weld).
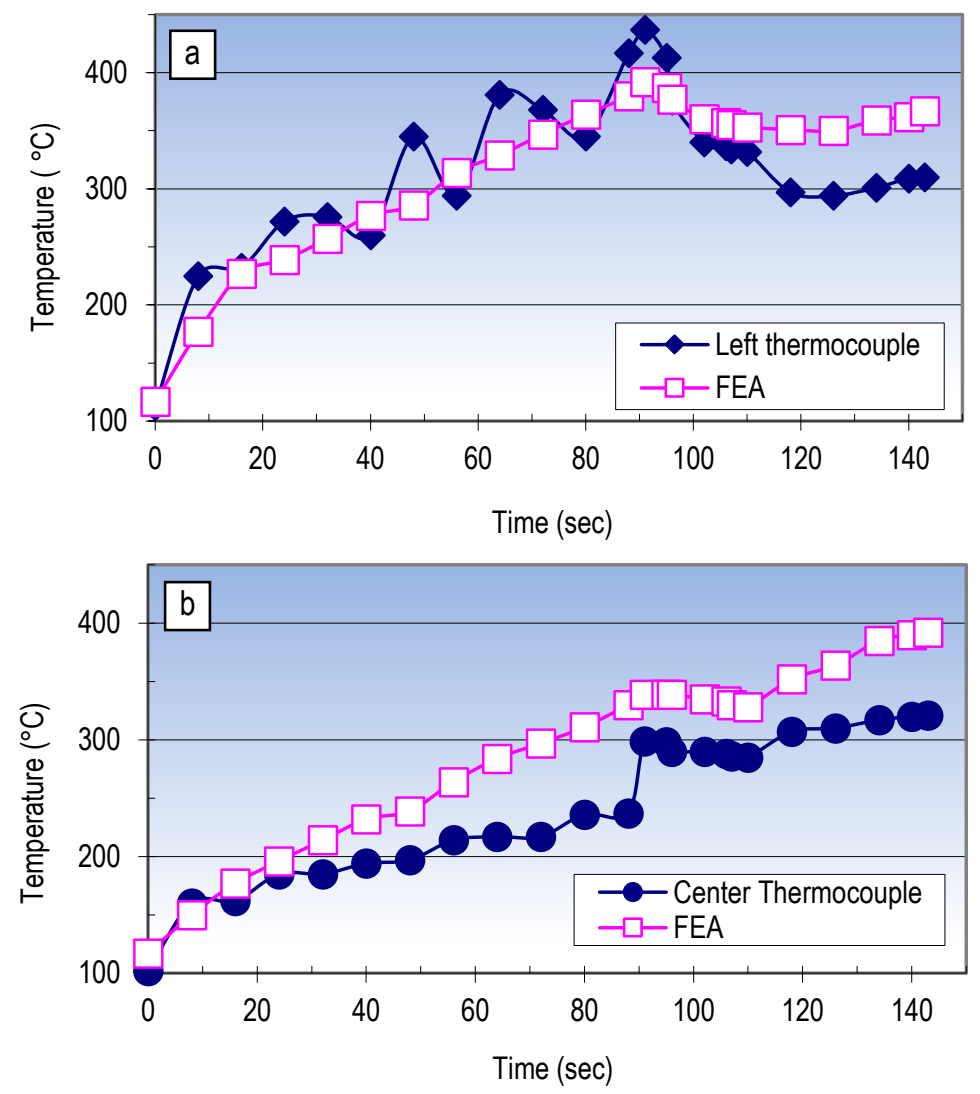


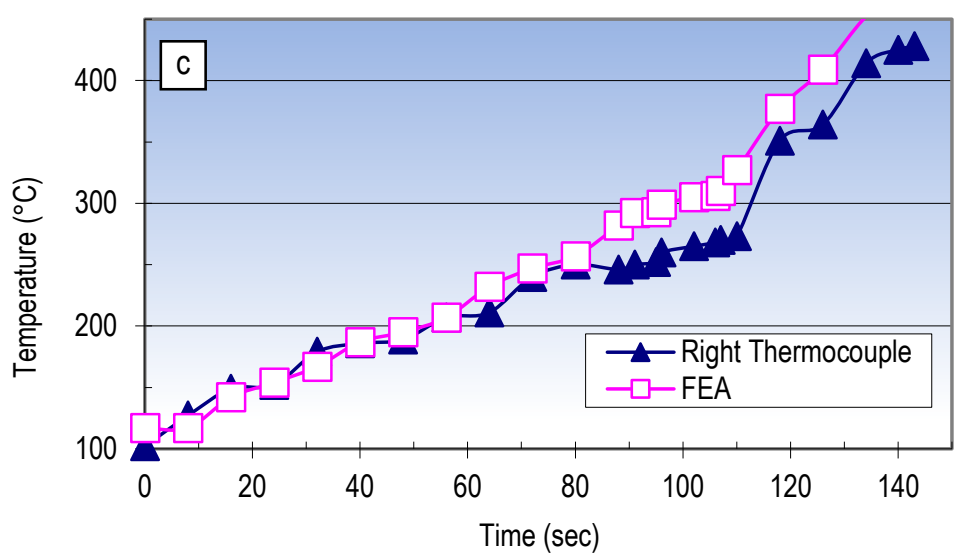

Figure 4: Temperature profiles at three thermocouple locations during preheating at (a) left, (b) center, and (c) right positions. GTAW preheating at 90A, 14.5V. Surface heating above the left thermocouple $(0-95 \mathrm{sec})$, switching to right location (95-110 sec), and then surface heating above the right thermocouple (110-145 sec).

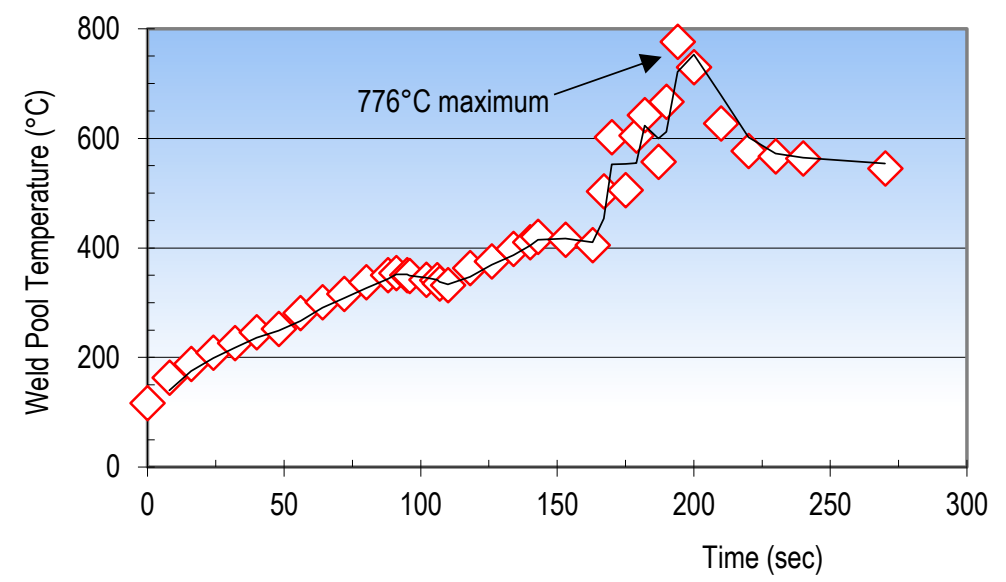

Figure 5: Finite element simulation of weld pool temperature. Preheating to $150^{\circ} \mathrm{C}$, left heating 0-95 sec, idle 95-110 $\mathrm{sec}$, right heating 110-145 sec, idle 145-165 sec, welding 165-195 sec at $90 \mathrm{~A}$, cooling after $195 \mathrm{sec}$.

Since the deviation of measured and predicted data was about $\pm 50^{\circ} \mathrm{C}$, it was assumed that the temperatures of all points in the weld, heat affected zone, and surrounding area could be predicted by finite element simulation to within $\pm 50^{\circ} \mathrm{C}$. Figure 5 shows the simulated temperature at the weld pool during preheating and welding. The maximum temperature at the weld pool was $776^{\circ} \mathrm{C}$ which was higher than both liquidus temperatures of $615^{\circ} \mathrm{C}$ (of the R356.0 aluminum filler rod), and $660^{\circ} \mathrm{C}$ (of the $\mathrm{A} 359$ aluminum matrix) $[26,27]$.

\subsection{Mechanical Tests}

Since a tensile specimen was notched near the weld, the maximum stress obtained from a tensile test was corrected by multiplying with a stress concentration factor. A sawed square slot of $1.5 \mathrm{~mm}$ width was approximated as a round-ended slot with $0.75 \mathrm{~mm}$ radius. The stress concentration factor $K_{t}$ was calculated from [28]:

Where

$$
K_{t}=C_{1}+C_{2}\left(\frac{h}{D}\right)+C_{3}\left(\frac{h}{D}\right)^{2}+C_{2}\left(\frac{h}{D}\right)^{3}=2.07
$$

h : slot length $=10 \mathrm{~mm}$

D : specimen depth $=15 \mathrm{~mm}$

$r \quad$ : radius of the end slot $=0.75 \mathrm{~mm}$

$$
\begin{aligned}
& C_{1}=0.953+2.136 \sqrt{\frac{h}{r}}-0.005\left(\frac{h}{r}\right) \\
& C_{2}=-3.255-6.281 \sqrt{\frac{h}{r}}+0.068\left(\frac{h}{r}\right)
\end{aligned}
$$




$$
\begin{aligned}
& C_{3}=8.203+6.893 \sqrt{\frac{h}{r}}+0.064\left(\frac{h}{r}\right) \\
& C_{4}=-4.851-2.793 \sqrt{\frac{h}{r}}-0.128\left(\frac{h}{r}\right)
\end{aligned}
$$

All 12 samples and replicates, welded at 2 variables and 2 levels, were carefully fabricated and tested. Tables 4 and 5 tabulate the tensile and four-point bending data from specimens welded at factorial test parameters. Resulted of the factorial experiments were collected and analyzed, from which optimal welding parameters of $85 \mathrm{~A}$ of $\mathrm{AC}$ current, and $260 \mathrm{~mm} / \mathrm{min}$ welding speed were selected for maximum tensile/bending strength. Notice that the optimal conditions were selected slightly outside of the testing ranges of $90-110 \mathrm{~A}$ and $120-250 \mathrm{~mm} / \mathrm{min}$.

\begin{tabular}{|c|c|c|c|c|c|c|c|}
\hline \multicolumn{2}{|c|}{ Run } & $\begin{array}{l}\text { Welding } \\
\text { current }(A)\end{array}$ & $\begin{array}{l}\text { Welding speed } \\
(\mathrm{mm} / \mathrm{min})\end{array}$ & $\begin{array}{l}\text { Max tensile } \\
\text { stress } \\
(\mathrm{MPa})\end{array}$ & $\begin{array}{l}\text { Relative tensile } \\
\text { strength } \\
\text { [weld/parent] (\%) }\end{array}$ & $\begin{array}{l}\text { Max } \\
\text { elongation } \\
(\%)\end{array}$ & $\begin{array}{l}\text { Relative ductility } \\
\text { [weld/parent] } \\
(\%)\end{array}$ \\
\hline \multirow[t]{3}{*}{1} & $\mathrm{a}$ & 110 & 120 & 138 & 57 & 2.6 & 60 \\
\hline & $b$ & & & 140 & 58 & 3.71 & 85 \\
\hline & c & & & 191 & 79 & 4.7 & 107 \\
\hline \multirow[t]{3}{*}{2} & $\mathrm{a}$ & 110 & 250 & 155 & 64 & 3.5 & 80 \\
\hline & $b$ & & & 166 & 69 & 4.6 & 105 \\
\hline & $c$ & & & 218 & 90 & 5.2 & 119 \\
\hline \multirow[t]{3}{*}{3} & $\mathrm{a}$ & 90 & 120 & 174 & 72 & 4.35 & 100 \\
\hline & $\mathrm{b}$ & & & 203 & 84 & 4.98 & 114 \\
\hline & $\mathrm{C}$ & & & 218 & 90 & 5.4 & 123 \\
\hline \multirow[t]{3}{*}{4} & $\mathrm{a}$ & 90 & 250 & 196 & 81 & 4.45 & 102 \\
\hline & $\mathrm{b}$ & & & 205 & 85 & 4.98 & 114 \\
\hline & c & & & 223 & 92 & 5.5 & 126 \\
\hline \multicolumn{3}{|c|}{ Parent MMC } & & 242 & 100 & 4.38 & 100 \\
\hline
\end{tabular}

Table 4: Factorial experiment. Tensile test results with three replicates.

Table 5: Factorial experiment. Four point bending test results without replicate.

\begin{tabular}{lcccccc}
\hline Run & $\begin{array}{l}\text { Welding } \\
\text { current } \\
\text { (A) }\end{array}$ & $\begin{array}{l}\text { Welding } \\
\text { speed } \\
\text { (mm/min) }\end{array}$ & $\begin{array}{l}\text { Max bending } \\
\text { stress (MPa) }\end{array}$ & $\begin{array}{l}\text { Relative bending } \\
\text { strength [weld/parent] } \\
(\%)\end{array}$ & $\begin{array}{l}\text { Maximum } \\
\text { bending strain } \\
\text { (\%) }\end{array}$ & $\begin{array}{l}\text { Relative bending } \\
\text { strain [weld/parent] } \\
\text { (\%) }\end{array}$ \\
\hline 1 & 110 & 120 & 199 & 80 & 2.39 & 290 \\
\hline 2 & 110 & 250 & 210 & 85 & 1.06 & 129 \\
\hline 3 & 90 & 120 & 296 & 100 & 1.36 & 165 \\
\hline 4 & 90 & 250 & 294 & 100 & 2.84 & 345 \\
\hline Parent MMC & & 248 & 100 & 0.822 & 100 \\
\hline
\end{tabular}

Table 6: Tensile test data for three replicates at optimal welding conditions.

Preheating following by welding at 85 A AC, $260 \mathrm{~mm} / \mathrm{min}$.

\begin{tabular}{lcccc}
\hline Replicate & $\begin{array}{l}\text { Max tensile stress } \\
(\mathrm{MPa})\end{array}$ & $\begin{array}{l}\text { Relative tensile strength } \\
\text { [weld/parent] }(\%)\end{array}$ & $\begin{array}{l}\text { Max elongation } \\
(\%)\end{array}$ & $\begin{array}{l}\text { Relative ductility } \\
\text { [weld/parent] }(\%)\end{array}$ \\
\hline 1 & 199 & 82 & 6.0 & 137 \\
2 & 202 & 83 & 5.2 & 118 \\
3 & 217 & 90 & 7.0 & 160 \\
\hline Average & 206 & 85 & 6.07 & 138 \\
\hline Parent MMC & 242 & 100 & 4.38 & 100 \\
\hline
\end{tabular}


Table 7: Four-point bending test data for three replicates at optimal welding conditions. Preheating following by welding at $85 \mathrm{~A} \mathrm{AC}, 260 \mathrm{~mm} / \mathrm{min}$.

\begin{tabular}{lcccc}
\hline Replicate & $\begin{array}{l}\text { Max bending stress } \\
(\mathrm{MPa})\end{array}$ & $\begin{array}{l}\text { Relative bending strength } \\
\text { [weld/parent] (\%) }\end{array}$ & $\begin{array}{l}\text { Max bending } \\
\text { strain (\%) }\end{array}$ & $\begin{array}{l}\text { Relative bending strain } \\
\text { [weld/parent] }(\%)\end{array}$ \\
\hline 1 & 244 & 100 & 1.1 & 133 \\
2 & 268 & 108 & 1.27 & 155 \\
3 & 278 & 112 & 1.5 & 182 \\
\hline Average & 263 & 106 & 1.29 & 156 \\
\hline Parent MMC & 248 & 100 & 0.822 & 100 \\
\hline
\end{tabular}

When welding at optimal conditions, the relative tensile strength and bending strength of the welded samples were $85 \%$ and $106 \%$ of those for the parent MMC (Table 6 ). The relative tensile ductility and relative bending strain were $138 \% 156 \%$ of those for and the parent MMC (Table 7). Ductility of both the tensile and bending specimens was experimentally measured to be higher than those of the parent MMC. The enhanced ductility was contributed by:

- $\quad$ addition of the soft and ductile Al-Si filler material in the weld,

- minimizing $\mathrm{SiC}$ particles redistribution and agglomeration in the weld, and

- lack of brittle aluminum carbide in the weld.

Thermal energy from the $85 \mathrm{~A}$ welding current melted both the filler material and the aluminum matrix, but the resulting weld pool cooled down rapidly due to the relatively fast welding speed of $260 \mathrm{~mm} / \mathrm{min}$ and the high thermal conductivity of the surrounding aluminum-based MMC. Finite element results showed the time window of about 15 seconds for a weld to melt and re-solidify again. During such short period, the $\mathrm{SiC}$ particles would not have sufficient time to redistribute themselves in a viscous melt, therefore, minimizing the chance for particle agglomeration and improving mechanical strength at the weld joint.

\subsection{Weld Microstructure}

Study of weld microstructure complemented the mechanical test results. Figures 5 and 6 illustrate typical microstructures of weld samples after tensile and bending tests, respectively. The weld zone and parent MMC were clearly distinguished after etching. The center of a weld zone contained more filler material and less reinforcement, while the SiC particles were uniformly distributed away from the weld center. A crack propagated through the weaker weld zone in the center rather than through the stronger weld zone between the weld and parent MMC. Figures 7 and 8 compare the microstructures of the parent $M M C$ and that at the weld zone of a typical welded specimen. The distribution of $\mathrm{SiC}$ particles in eutectic zones was similar in both cases, and there were isolated voids in both the welded zone and in the cast MMC.

Prolong exposure of $\mathrm{SiC}$ to heated aluminum in thermodynamically favorable conditions would decompose the $\mathrm{SiC}$ to form a brittle and needle-like aluminum carbides $\mathrm{Al}_{4} \mathrm{C}_{3}$ according to the reaction (1). As expected and shown in Fig. 9, laser drilling of $\mathrm{A} 359 / \mathrm{SiC}$ at high power density (i) melted the aluminum matrix and maintained a high temperature due to sequential laser pulses applying at the same location, (ii) transformed $\mathrm{SiC}$ into needle-like $\mathrm{Al}_{4} \mathrm{C}_{3}$, and (iii) redistributed $\mathrm{SiC}$ in the microstructure. Other researchers also observed $\mathrm{Al}_{4} \mathrm{C}_{3}$ in welded $\mathrm{Al} / \mathrm{SiC} \mathrm{MMCs}$. The $\mathrm{Al}_{4} \mathrm{C}_{3}$ needles, typically 20-50 $\mu \mathrm{m}$ long and easily seen under an optical microscope, were reported due to thermal decomposition of $\mathrm{SiC}$ in an aluminum matrix in tungsten inert gas welding [6], $\mathrm{CO}_{2}$ laser welding [7], and YAC laser machining [12].

In this study, the needle-shape $\mathrm{Al}_{4} \mathrm{C}_{3}$ was not observed with the optical microscope in any $\mathrm{A} 359 / \mathrm{SiC} / 10 \mathrm{p} \mathrm{MMC}$ samples welded at optimal conditions. Lack of $\mathrm{Al}_{4} \mathrm{C}_{3}$ in welded microstructure of the $\mathrm{MMC}$ could be due to:

a) The reaction (1) did not happen and no $\mathrm{Al}_{4} \mathrm{C}_{3}$ was formed, or

b) The reaction (1) happened and $\mathrm{Al}_{4} \mathrm{C}_{3}$ was formed, but then the reaction reversed due to additional silicon in the weld, or

c) The reaction (1) happened and formed $\mathrm{Al}_{4} \mathrm{C}_{3}$, but the resulting $\mathrm{Al}_{4} \mathrm{C}_{3}$ needles were too small to be seen even at high magnification optical microscopy, or

d) The reaction (1) happened and formed $\mathrm{Al}_{4} \mathrm{C}_{3}$, but it was dissolved when contact with water during metallographic sample preparation. 


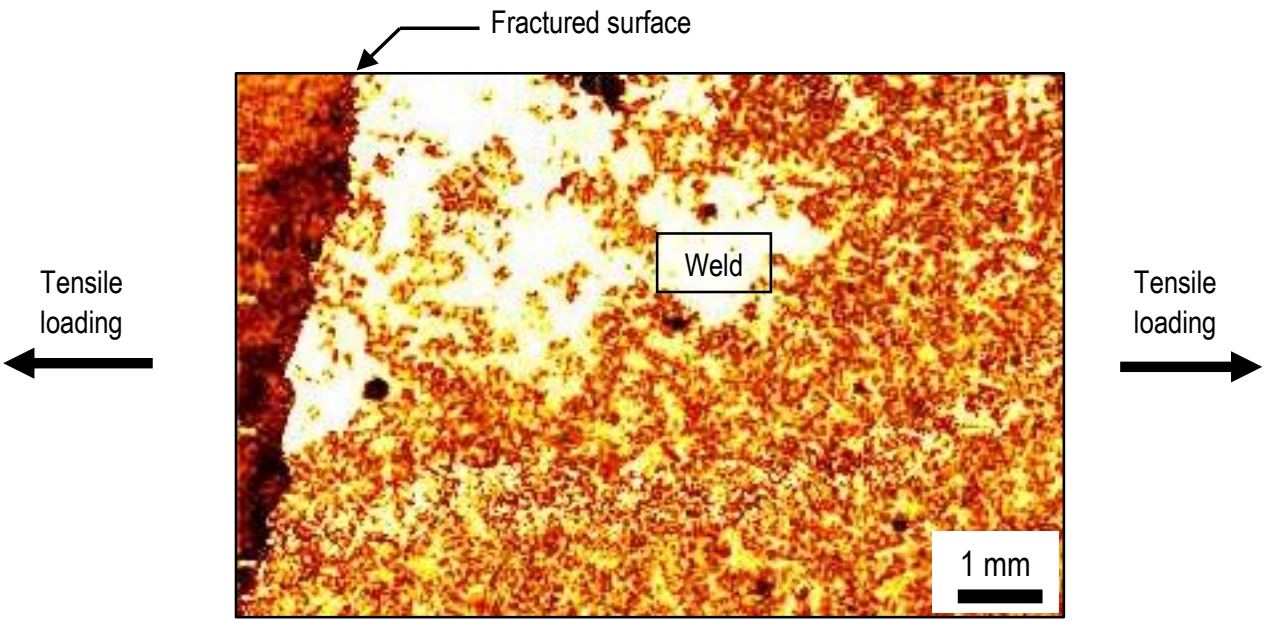

Figure 5: Fractured surface and microstructure of typical tensile specimen.

Preheating and GTAW at 85 A AC, 260 mm/min; Keller etching.
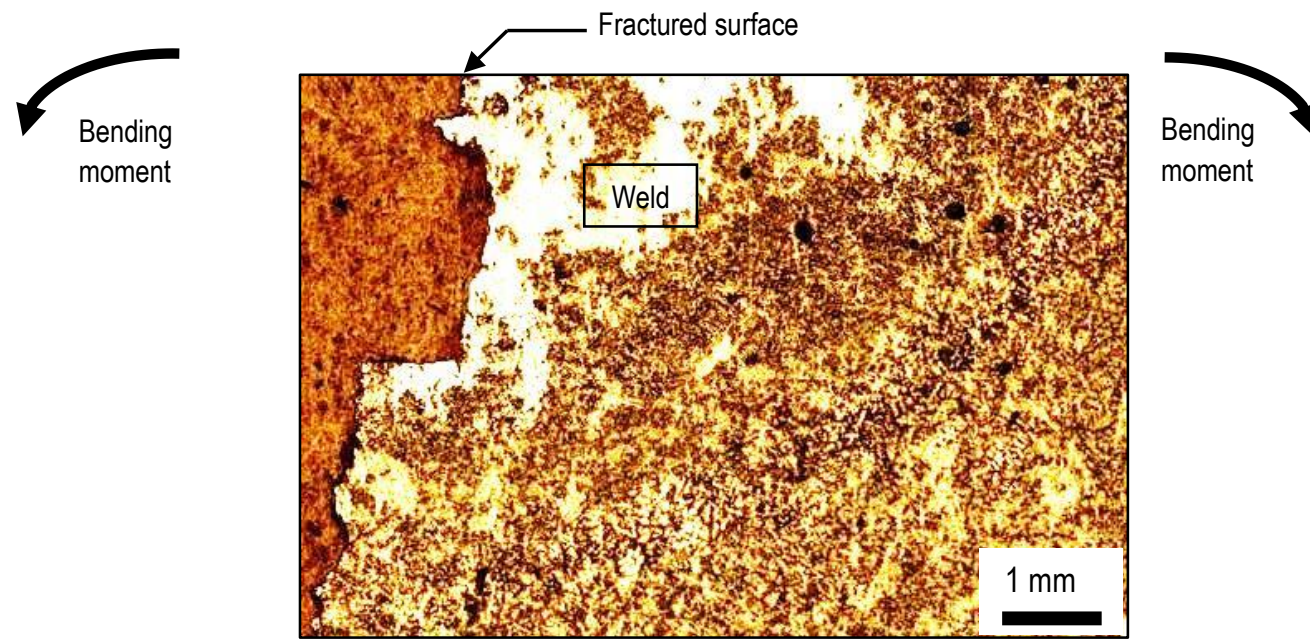

Figure 6: Fractured surface and microstructure of typical four-point bending specimen. Preheating and GTAW at $85 \mathrm{~A} \mathrm{AC,} 260 \mathrm{~mm} / \mathrm{min}$; Keller etching.

Although the aluminum carbide $\mathrm{Al}_{4} \mathrm{C}_{3}$ can be affected by moisture, it was unlikely that the $\mathrm{Al}_{4} \mathrm{C}_{3}$ was dissolved in water during sample preparation in this study. The metallurgical samples were hand ground and washed with water; a short exposure time ( $<1$ hour) of a sample in water during preparation was not sufficient for the intermetallic compound $\mathrm{Al}_{4} \mathrm{C}_{3}$ to completely dissolve. The $\mathrm{Al}_{4} \mathrm{C}_{3}$, however, can be disintegrated in water after a very long exposure time, says 120 hours [9]. The same metallographic sample preparation procedure after laser processing of similar MMCs, i.e., grinding and washing in water, revealed the 20-50 $\mu \mathrm{m}$ long $\mathrm{Al}_{4} \mathrm{C}_{3}$ needles (Fig. 9) but not in the samples welded at optimal conditions in this study (Fig. 8).

The relatively high weld strengths were contributed by strong adhesion at the weld zone and absence of the brittle $\mathrm{Al}_{4} \mathrm{C}_{3}$. The formation of $\mathrm{Al}_{4} \mathrm{C}_{3}$ depended on temperature, time, and power delivered to the weld $[3,7,11]$. Alloying and thermal control were utilized to suppress the formation of harmful $\mathrm{Al}_{4} \mathrm{C}_{3}$ in this study: alloying was formed by adding silicon from a filler rod -thus effectively reversed the reaction (1)- and lowering the welding temperature was achieved by welding using a low AC current at relatively fast welding speed. 


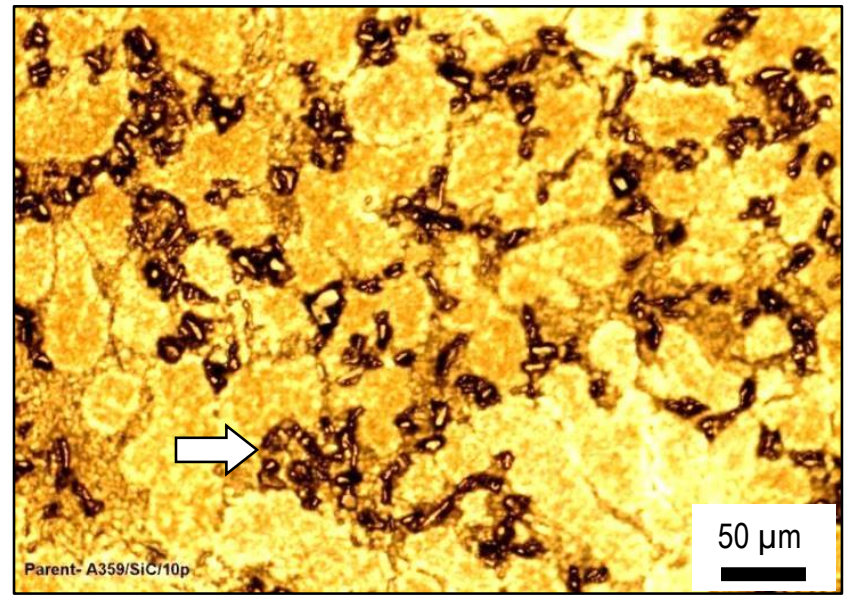

Figure 7: Microstructure of as-cast A359/SiC/10p.

The typical SiC particles (at arrow) are in eutectic zone of the cast MMC.

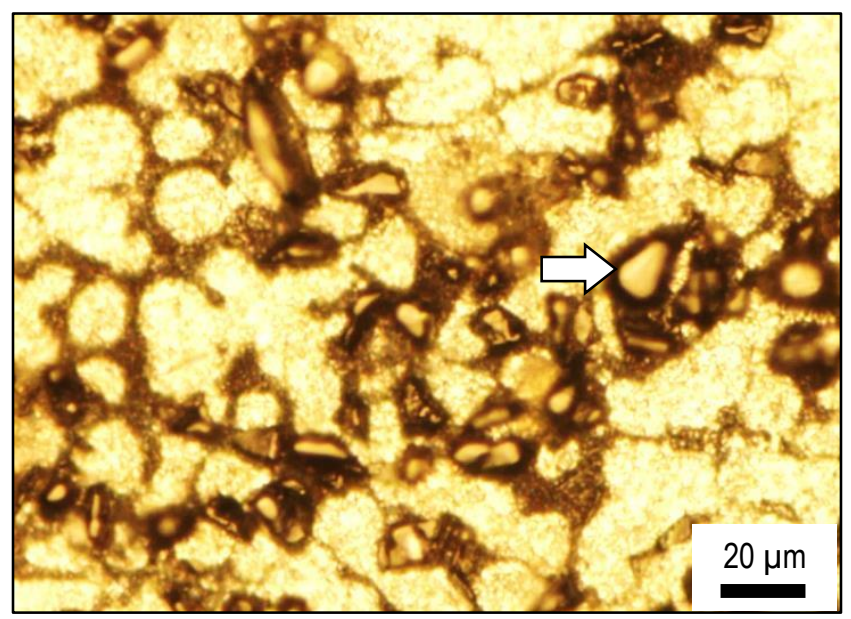

Figure 8: Microstructure of the welded region of A359/SiC/10p. Notice the absence of needle-shape $\mathrm{Al}_{4} \mathrm{C}_{3} \mathrm{near}$ a $\mathrm{SiC}$ particle (at arrow). Preheating and GTAW at $85 \mathrm{~A} \mathrm{AC,} 260 \mathrm{~mm} / \mathrm{min}$.

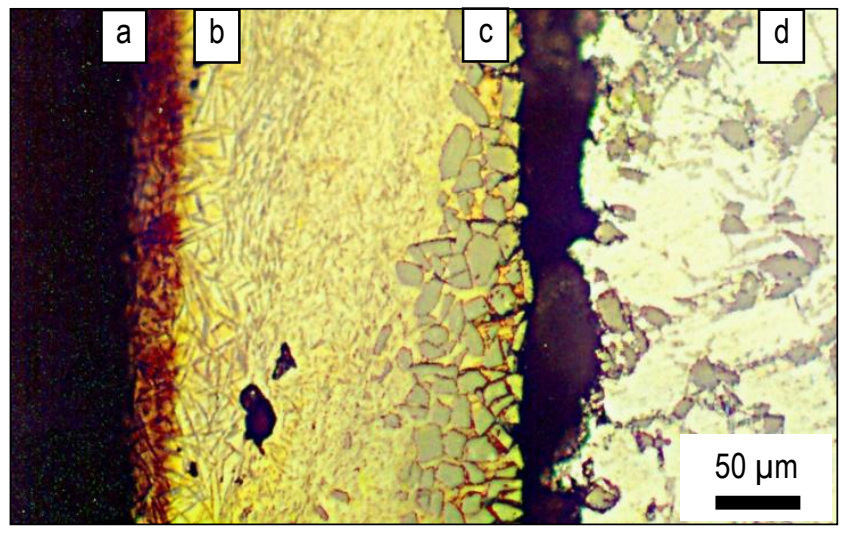

Figure 9: Microstructure of $\mathrm{A} 359 / \mathrm{SiC}$ after drilling with YAG laser (a) laser cut area, (b) $\mathrm{Al}_{4} \mathrm{C}_{3}$ rich area, (c) $\mathrm{SiC}$ rich area, and (d) parent A359 aluminum MMC. Notice the crack dividing zones (c) and (d). The needle-like $\mathrm{Al}_{4} \mathrm{C}_{3}$ precipitates are still visible in zones (a) and (b) after ground, polished, and washed in water during sample preparation. 
Aluminum reacts with $\mathrm{SiC}$ to form aluminum carbide $\mathrm{Al}_{4} \mathrm{C}_{3}$ and silicon $\mathrm{Si}$ as predicted in reaction (1), an addition of silicon from the filler metal (into the right side of the reaction) would reverse the reaction and reduce the amount of $\mathrm{Al}_{4} \mathrm{C}_{3}$. For a chemical reaction to happen, the free energy change of that reaction must be less than zero. Ellis [3] proposed that the free energy for the reaction (1) can be calculated from:

$$
\Delta G=113900-12.06 T \ln T+8.92 \times 10^{-3} T^{2}+7.53 \times 10^{-4} T^{-1}+21.5 T+3 R T \ln \left(a_{[\operatorname{Si}]}\right)
$$

Where $\quad a_{[\mathrm{Si}]} \quad$ : activity of silicon in aluminum liquid $=0.1$

$$
\begin{array}{ll}
a_{[S \mathrm{Si}} & : \text { activity of silicon in aluminum liquid }= \\
R & : \text { gas constant }=8.314 \mathrm{~J} / \mathrm{mol}{ }^{\circ} \mathrm{K} \\
T & : \text { absolute temperature }\left({ }^{\circ} \mathrm{K}\right) \\
\Delta G & : \text { change of reaction free energy }(\mathrm{J} / \mathrm{mol})
\end{array}
$$

The activity of $\mathrm{Si}$ in liquid aluminum, $a_{[\mathrm{Si}}$, was approximately 0.1 for the A356/SiC MMCs [7]. The silicon content in A359 aluminum (8.5-9.5 wt\% Si) was slightly higher than that for A356 aluminum (6.5-7.5 wt\% $\mathrm{Si}$ ) of the filler material R356.0 (Table 2). Since majority of the weld groove was filled with the filler material (Figs. 5, 6), it was reasonable to approximate the silicon activity to be 0.1 for A356 aluminum when welding A359/Si. Substituting the values of the $a_{[S i]}$ and gas constant into equation (7) to get:

$$
\Delta G=113900-12.06 T \ln T+8.92 \times 10^{-3} T^{2}+7.53 \times 10^{-4} T^{-1}-35.93 T
$$

The temperature $T=1031.6^{\circ} \mathrm{K}\left(758.6 \approx 759^{\circ} \mathrm{C}\right)$ that made the right hand side of equation (8) zero can be solved numerically or graphically (Fig. 10). Thus, the reaction (1) only occurs when the free energy $\Delta G \leq 0$, or when the threshold temperature $T \geq 759^{\circ} \mathrm{C}$. Below this critical temperature, the thermodynamic driving force, as dictated by $\Delta G$, is positive which would prevent the reaction (1) from happening, therefore suppressing the formation of $\mathrm{Al}_{4} \mathrm{C}_{3}$. Other researchers have reported the threshold temperatures for $\mathrm{Al}_{4} \mathrm{C}_{3}$ formation were as low as $650^{\circ} \mathrm{C}[9], 727^{\circ} \mathrm{C}$ [3], or as high as $827^{\circ} \mathrm{C}$ [7].

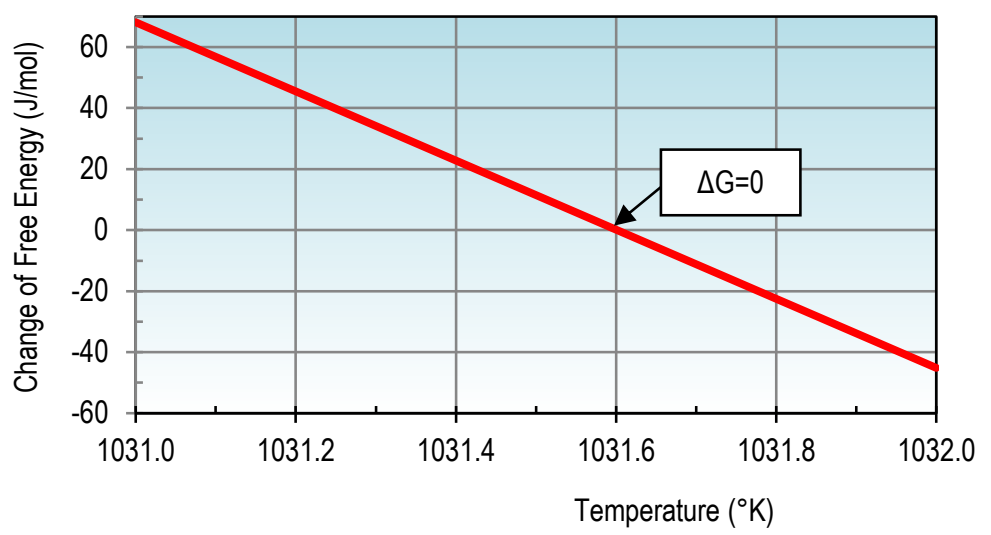

Figure 10: Graphical solution of equation (8)

In this study, the temperature of any point in the weld zone can be estimated by finite element method. The FEA predicted the highest temperature at a node in the weld pool was approximately $776^{\circ} \mathrm{C}\left(1049^{\circ} \mathrm{K}\right)$ for a short duration of 5-7 seconds (Fig. 5), after which the temperature dropped substantially. With the accuracy of $\pm 50^{\circ} \mathrm{C}$ from FEA, the maximum temperature range was therefore $776 \pm 50^{\circ} \mathrm{C}$ or $726-826^{\circ} \mathrm{C}$ which was in the proximity temperature of $\mathrm{Al}_{4} \mathrm{C}_{3}$ formation $\left(759^{\circ} \mathrm{C}\right)$. Although the temperature criterion was at the border line, perhaps the short resident time of the welding pool $(5-7 \mathrm{sec})$ did not allow sufficient time for the reaction (1) to happen. This was confirmed with high magnification optical microscopy examination when no $\mathrm{Al}_{4} \mathrm{C}_{3}$ near a $\mathrm{SiC}$ particle can be found in all optimally welded specimens (Fig. 8).

Quality of the weld was also assessed with Vicker microhardness measurement in the matrix across a weld. Figure 11 plots the microhardness data of the matrix as a function of distance away from a weld center of three weld specimens. The microhardness near center of a weld was similar to that of the parent material, but it increased near the joint interface. A low hardness value at the weld center also indicated the absence of $\mathrm{Al}_{4} \mathrm{C}_{3}$ precipitates in that area. The microhardness peaks, 3-5 mm away from the weld center and near the weld/parent material interface, perhaps were due to (i) smaller dendrite spacing due to different cooling rates, or (ii) a denser SiC particle density (Figs. 5 and 6). A higher SiC particle density would form high dislocation density in a smaller dendrite by residual strains due to thermal mismatch between the aluminum matrix and ceramic reinforcement, which in turn increased the matrix hardness and matrix strength at this location. 


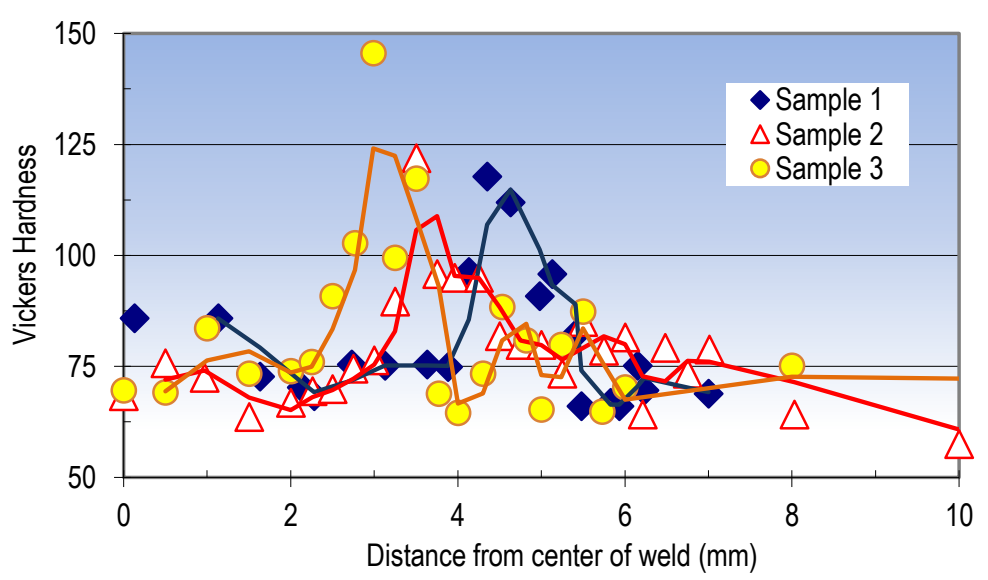

Figure 11: Vicker microhardness of the matrix across the weld of three specimens. Each line is the moving average of two data points on a weld zone. Microhardness test at $25 \mathrm{gf}, 10 \mathrm{~s}$. Preheating and GTAW at 85 A AC, $260 \mathrm{~mm} / \mathrm{min}$ welding speed.

\section{CONCLUSIONS AND RECOMMENDATIONS}

Weldability of A359/SiC/10p metal matrix composite using gas tungsten arc welding and R356.0 filler was determined by systematically identifying the influence of the welding variables on the weld quality. This study shows:

1. Thermal control was necessary to obtain favorable distribution of $\mathrm{SiC}$ particles in the weld pool. Preheating of a weldment to $150^{\circ} \mathrm{C}$ following by GTAW torch surface preheating in the vicinity of the weld helped to control the temperature and viscosity at the weld. Finite element analysis predicted the temperature in the vicinity of a weld to within $\pm 50^{\circ} \mathrm{C}$.

2. Reasonable mechanical properties of the weldments were obtained. When welding at optimal conditions and adding additional silicon from filling rod, the relative tensile and bending strengths were $85 \%$ and $106 \%$ of those from the parent $M M C$, and the resulting ductility from tensile and bending tests were $138 \%$ and $156 \%$ compared to those from the parent material.

3. Formation of harmful $\mathrm{Al}_{4} \mathrm{C}_{3}$ during welding of the $\mathrm{A359} / \mathrm{SiCp}$ composite was suppressed. This was due to the addition of silicon content from the filler material, and favorable temperature control in the weld. The threshold temperature to form $\mathrm{Al}_{4} \mathrm{C}_{3}$ in $\mathrm{Al}-\mathrm{SiC}$ composite was calculated to be $759^{\circ} \mathrm{C}\left(1032^{\circ} \mathrm{K}\right)$. The maximum temperature in the weld pool was calculated to be in the range $726-826^{\circ} \mathrm{C}$ and remained for about $5-7$ seconds. This short time duration and low weld temperature did not allow $\mathrm{Al}_{4} \mathrm{C}_{3}$ to form in a weld. The absence of 20-50 $\mu \mathrm{m}$ needle-like $\mathrm{Al}_{4} \mathrm{C}_{3}$ was confirmed with microstructure and microhardness study.

Additional works could be done to confirm the results:

a) Scanning electron microscopy can be used at very high magnification to find out if the silicon carbide needles have started at the $\mathrm{SiC}$ and aluminum interface after welding at optimal conditions.

b) The dog-bone shaped tensile specimens with though thickness butt weld can be tested to verify the tensile properties of welded composites.

c) Transmission electron microscopy can be used to study the dislocation densities in the weld and heat affected zone to confirm the microhardness results.

\section{REFERENCES}

[1] TWI. Joining of aluminium based metal matrix composites: Initial study (2014). http://www.twi-global.com.

[2] Schwartz MM. Joining of Composite Matrix Materials, ASM International, Materials Park, OH, 1994; 89-90.

[3] Ellis MBD. Journal of Material Review (1996). 41: 41-58.

[4] Urena A, Gomez de Salazar JM, Gil L, Escalera MD, and Baldonedo JL. J Microscopy (1999). 196: 124-136.

[5] Urena A, Escalera MD, and Gil L. Influence of Interface Reactions on Fracture Mechanism in TIG Arc-Welded Aluminum Matrix Composites, J Composites Science and Technology (2000). 60: 613-622.

[6] Chen M, Wu C, and Gao J. (2002). Welding of SiC Particle Reinforced 6061 Al Matrix Composites with Pulsed TIG, Transactions of Nonferrous Metals Society of China 12(5): 805-810. 
[7] Gopinathan S, McCay MH, and McCay TD. (1993). Continuous Wave CO 2 Laser Welding of SiC/A356 Al Metal Matrix Composites: An Analytical Estimate for Formation of Aluminum Carbide, J Processing of Advanced Materials 3:213-224.

[8] Mathers G. (1997). The Welding of Aluminum and Its Alloys, Woodhead Publishing Limited, Cambridge, UK; 2002.

[9] Park JK and Lucas JP (1997). Moisture Effect on SiCp/6061 Al MMC: Dissolution of Interfacial $\mathrm{Al}_{4} \mathrm{C}_{3}$, J Scipta Materialia 37(4) 511-516.

[10] Dahotre NB, McCay MH, McCay MD, Goinathan S, and Sharp CM. (1992). Laser Joining of Metal Matrix Composites, Proceedings of Machining of Composites Materials Symposium, ASME, Chicago, Illinois; 167-173.

[11] Dahotre NB, McCay TD, and McCay MH. (1994). Laser Induced Liquid Phase Reaction Synthesis Assisted Joining of MMCs, J Materials and Manufacturing Processes; 9(3): 447-466.

[12] Hung NP, Jana S, Yang L, and Heng CH. (1995). Laser Drilling of Cast Metal Matrix Composites, Proceedings, ASME, New York, AMD 208 MD 59; 87-92.

[13] Gomez de Salazar JM and Barrena MI. (2003). Dissimilar fusion welding of AA7020/MMC reinforced with $\mathrm{Al}_{2} \mathrm{O}_{3}$ particles. Microstructure and mechanical properties. J Materials Science \& Engineering A; A352: 162-168.

[14] Wang HM, Chen YL, and Yu LG. (2000). In-situ weld-alloying: laser beam welding of SiCp /6061Al MMC. J Materials Science \& Engineering A; A293: 1-6.

[15] Kannan P, Balamurugan K, and Thirunaavukkarasu K. (2012). Reducing the Particle Fracture in Dissimilar Friction Welds by Introducing Silver Interlayer. J Recent Technology and Engineering; 1:2, 159-160.

[16] Lee JA, Carter RW, and Ding J. (1999). Friction stir welding for aluminum metal matrix composites. NASA TM1999-209876 report.

[17] Prater T. (2014). Friction Stir Welding of Metal Matrix Composites for use in aerospace structures. J Acta Astronautica 93; 336-373.

[18] Zhou Y, Li Z, Hu L, Fuji A, and North TH. Mechanical Properties of Particulate MMC/AISI 304 Friction Joints; J Iron and Steel Institute of Japan; 1995; 35:10, 1315-1321.

[19] Bozkurt Y, Kentli A, Uzun H, and Salman S. (2012). Experimental investigation and prediction of mechanical properties of friction stir welded aluminum metal matrix composite plates; J Materials Science ISSN 1392-1320; 18 (4): 336-340.

[20] JayaramanM, Sivasubramanian R, Balasubramanian V. (2009). Effect of process parameters on tensile strength of friction stir welded cast LM6 aluminium alloy joints. J Material Science and Technology; 25:5, 655-664.

[21] Miller SF, Arul SG, Kruger GH, Pan TY, and Shih AJ. (2011). Effect of Localized Metal Matrix Composite Formation on Spot Friction Welding Joint Strength. J. Engineering Materials and Technology; 133: 031009 1-8.

[22] Huang J, Dong Y, Zhang J, Wan Y, and Zhou G. (2005). Reactive Diffusion Bonding of SiCp/Al Composites by Insert Powder Layers with Eutectic Composition. J. Material Science and Technology; 21:5, 779-781.

[23] Rosenberg RA, Goeppner GA, Noonan JR, Farrell WJ, and Ma Q. (1999). High power X-ray welding of metalmatrix composites. US patent 5994660.

[24] CASTI Metals Data Book Series. CASTI Metals Blue Book Welding Filler Metals (2002). ASM International, Materials Park, OH, 252.

[25] MC-21 Inc.(2014). http://mmc-assess.tuwien.ac.at/mmc/cat/Suppliers.html.

[26] Procast Technologies (2014). http://www.procast.ca/alloy-information-aluminum-a356-0.php.

[27] Beck Aluminum (2014). http://www.francismanufacturing.com/media/958/MSDS 359-Alloy.pdf.

[28] Pilkey WD. (1994). Formulas for stress, strain, and structural matrices; John Wiley \& Sons Inc. 